\title{
Seasonal use of bridges as day-roosts by bats in the Trans-Pecos of Texas
}

\author{
Richard D. Stevens ${ }^{1,2 *}$, Carlos J. Garcia ${ }^{1}$, Emma E. Guest ${ }^{1}$, Austin Hargrove ${ }^{1}$, Macy A. Krishnamoorthy ${ }^{3}$, Carl F. Rickert ${ }^{3}$, Emma M. Sanchez ${ }^{1}$, Erin \\ E. Stukenholtz ${ }^{1}$, Colton A. Triplett ${ }^{1}$, Holly Wilson ${ }^{1}$, and Stirling J. Robertson ${ }^{4}$ \\ 1 Department of Natural Resources Management, Texas Tech University, Lubbock, 79409, Texas, USA. Email: richard.stevens@ \\ ttu.edu (RDS), carlos.j.garcia@ttu.edu (CJG), eeg89@txstate.edu (EEG), austinhargrove@ufl.edu (AH), emma.m.sanchez@ttu.edu \\ (EMS), erin.stukenholtz@ttu.edu (EES), colten.triplett@ttu.edu (CAT), holly.wilson@ttu.edu (HW). \\ ${ }^{2}$ Natural Science Research Laboratory, Museum of Texas Tech University, Lubbock, 79409. Texas, USA. \\ ${ }^{3}$ Department of Biological Sciences, Texas Tech University, Lubbock, 79c.409. Texas, USA. Email: macy.krishnamoorthy@ttu.edu \\ (MAK), rickertranchwmc@gmail.com (CFR). \\ ${ }^{4}$ Texas Department of Transportation, Environmental Affairs Division, 125 E. $11^{\text {th }}$ Street, 78701, Austin. Texas, USA. Email: stir- \\ ling.robertson@txdot.gov (SJR). \\ ${ }^{*}$ Corresponding author
}

\begin{abstract}
Bats commonly use highway infrastructure as day- or night-roosts. Nonetheless, little is known regarding how regularly bats use these structures or whether they do so only on a seasonal basis. We surveyed 13 parallel box beam bridges along 15 km of State Highway 17 in Jeff Davis County, Texas monthly for 12 months to examine seasonality of day-roost use. Bats using bridges, ranked based on abundance, were: Tadarida brasiliensis, Myotis velifer, M. californicus/ciliolabrum, M. yumanensis, Antrozous pallidus, and M. thysanodes. Myotis velifer, M. californicus/ ciliolabrum, and M. yumanensis exhibited significant differences among bridges and significant seasonality in roost use. Tadarida brasiliensis exhibited significant differences among bridges but no significant seasonality of bridge use. Seasonality of use of bridges as day-roosts likely reflects seasonal patterns of distribution of species in the Trans-Pecos. Moreover, these results suggest that surveys of bats roosting in highway infrastructure should be planned carefully and consider the seasonal nature of roost use.
\end{abstract}

Generalmente los murciélagos utilizan la infraestructura de carreteras como perchas durante el día y la noche. No obstante, se conoce muy poco con que regularidad los murciélagos utilizan dichas estructuras, o si las utilizan de manera estacional. Durante12 meses, hemos examinado 13 puentes de vigas cuadradas y paralelas a lo largo de $15 \mathrm{Km}$ de la Carretera Estatal 17 en el condado de Jeff Davis, Texas, para examinar la estacionalidad en el uso diurno de las perchas. Los murciélagos que utilizan los puentes fueron clasificados en base a su abundancia, en el siguiente orden: Tadarida brasiliensis, Myotis velifer, M. californicus/ciliolabrum, M. yumanensis, Antrozous pallidus and M. thysanodes. Myotis velifer, M. californicus/ciliolabrum and $M$. yumanensis exhiben diferencias significativas entre puentes y también estacionalidad significativa en el uso de perchas. Tadarida brasiliensis exhibe diferencias significativas entre puentes pero no muestra estacionalidad significativa en el uso de los puentes. La estacionalidad en la utilización de puentes como perchas diurnas probablemente refleja los patrones estacionales de distribución de la especie en el Trans-Pecos. Por otra parte, los resultados sugieren que estudios de murciélagos basados en la infraestructura de carreteras deben de ser planeados cuidadosamente considerando la naturaleza estacional del uso de las perchas.

Keywords: Chiroptera; Myotis velifer; seasonality; Tadarida brasiliensis; transportation infrastructure.

@ 2021 Asociación Mexicana de Mastozoología, www.mastozoologiamexicana.org

\section{Introduction}

Many organisms, especially higher vertebrates, use daytime or nighttime resting places (e. g., burrows, dens, nests, roosts) to sleep, rest, or escape the elements. Bats may spend more than $50 \%$ of their time in day-roosts (Kunz and Pierson 1994). Not only do roosts provide a place to rest and protection from weather, they protect bats from predators, as well as facilitate day-to-day activities such as mating, raising of young, and torpor/hibernation (Kalcounis-Ruppell et al. 2005; Mering and Chambers 2014). As a result, decisions as to where and what kind of roost to use have fitness consequences (Kunz 1982).

Bats are highly variable in their use of day-roosts (Kunz and Lumsden 2003). Natural roosts include foliage (Constantine 1958), tree cavities (Pierson 1998), rock crevices (Vaughan and O'Shea 1976), and caves (Davis et al. 1963), among others. Bats also use a variety of manmade struc- tures as roosts including buildings (Brigham and Fenton 1986), attics (Humphrey and Cope 1976), mines (Fenton 1970), bridges (Davis and Cockrum 1963), and culverts (Bender et al. 2010).

Twenty-four species of bats in North America frequently use highway infrastructure as day-roosts (Keeley and Tuttle 1999). The most frequently used structures are large and long box culverts or parallel box beam bridges (Keeley and Tuttle 1999). In a study by Keeley and Tuttle (1999) spanning 25 of the states of the United States, approximately $9 \%$ of bridges and culverts were used as day roosts by bats. In North Carolina, three species of bats roosted under 15 of 23 bridges (Felts and Webster 2003). Similar patterns have been described in more focused studies from central New Mexico (Geluso and Mink 2009), southern Illinois (Feldhamer et al. 2003), and Texas (Meierhofer et al. 2018). 
The Trans-Pecos region of west Texas is home to 27 species of bats and represents the ecoregion with the greatest bat diversity in Texas, which consists of 34 species (Schmidly and Bradley 2016; Krejsa et al. 2020). Most bats occur in this region seasonally, being most numerous during summer and migrating south to México and other locales to overwinter (Higginbotham and Ammerman 2002). Our objectives were to characterize bridge-specific and season-specific use of bridges as day-roosts by bats in the Trans-Pecos region of Texas.

\section{Methods}

Study area and sampling of bats. Thirteen bridges were examined monthly along an approximately $15 \mathrm{~km}$ stretch of Texas State Highway (SH) 17 in Jeff Davis County, Texas between June 2018 and May 2019 (Figure 1). All bridges were parallel box beam bridges, typically with six parallel box beams with expansion joints up to $15 \mathrm{~cm}$ in width. Bridges were distributed across the riparian corridor of Limpia Creek and typically more than $2 \mathrm{~m}$ and always less than $4 \mathrm{~m}$ in height off the ground. Joints were inspected for bats with the aid of a spotlight. Individuals of each species except $T$. brasiliensis were enumerated. Quantities of $T$. brasiliensis were recorded into six bins $(0,1-10,11-100,101-$ $1000,1001-5000,5000)$. Some bats were captured periodically using 24 inch forceps, identified and sexed.

Myotis ciliolabrum and M. californicus are difficult to distinguish in the field (Ammerman et al. 2012). Accordingly, we did not distinguish between these two species while surveying bridges. Prior to this study, several specimens from this stretch of Texas SH 17 were collected and identified as M. ciliolabrum based on the key to the skulls in Ammerman et al. (2012). These are housed in the Mammal Collection of the Natural Science Research Laboratory, Museum of Texas Tech University. Myotis ciliolabrum tends to occur at higher elevations than does M. californicus (Constantine 1998; Holloway and Barclay 2001), including elevations where it was observed in this study. It is likely that these individuals were $M$. ciliolabrum, but we did not collect any museum vouchers and cannot be sure. Consequently, we herein refer to these two species collectively as M. californicus/ciliolabrum. Keely and Tuttle (1999) listed only M.

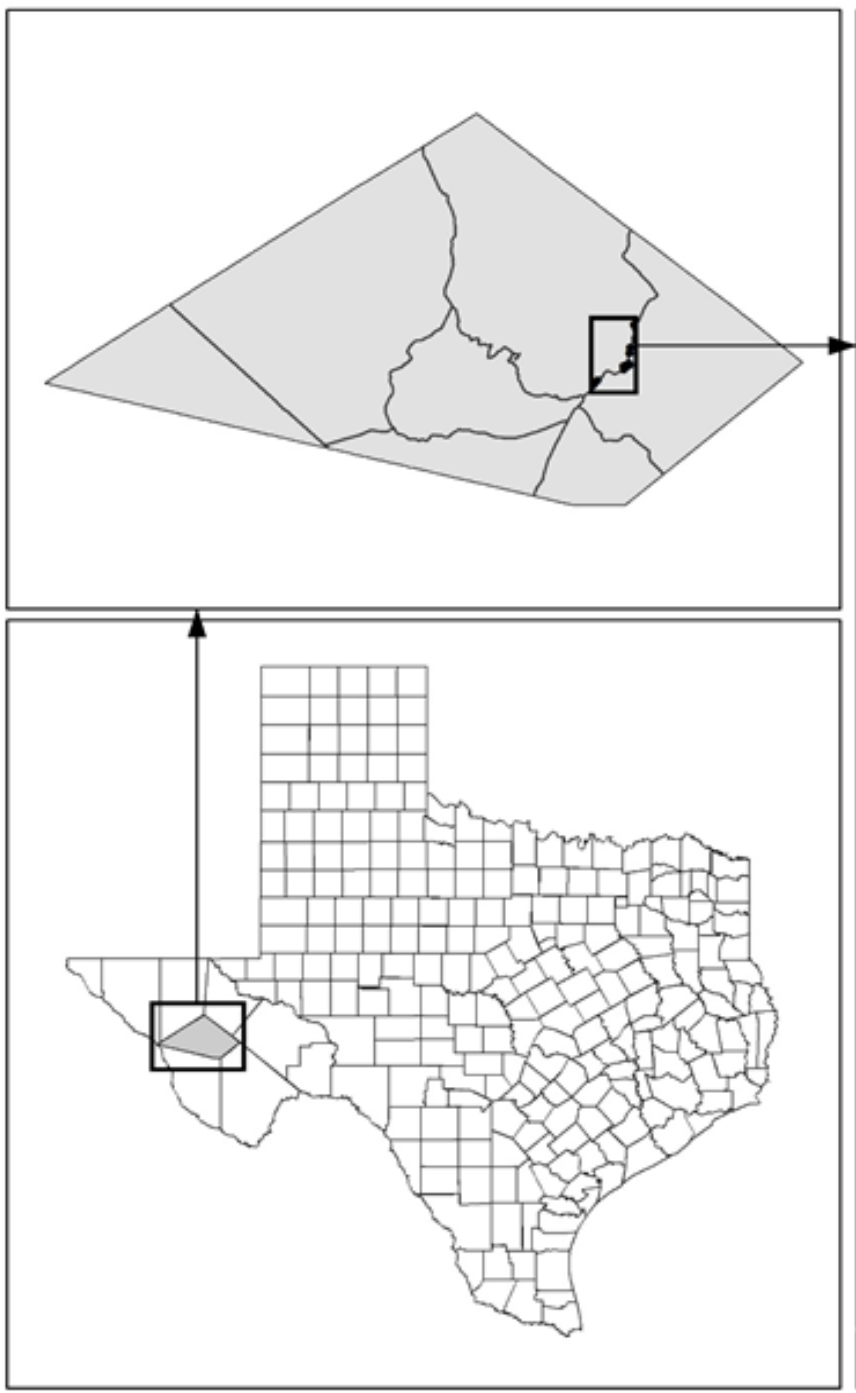

\section{Legend \\ - Bridges \\ 1 - Tadarida brasiliensis \\ 2 - Myotis velifer \\ 3 - Myotis californicus/ciliolabrum \\ 4 - Myotis yumanensis \\ 5 - Myotis thysanodes \\ 6 - Antrozous pallidus}

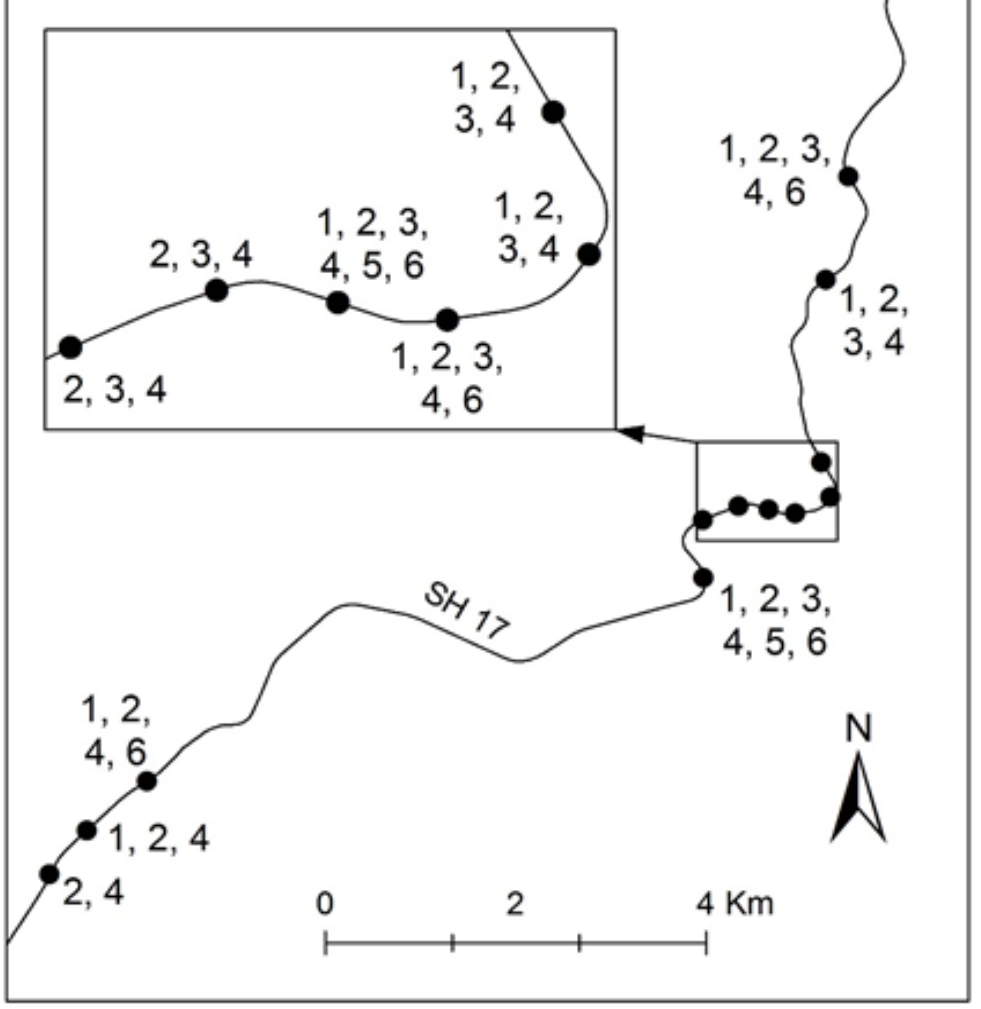

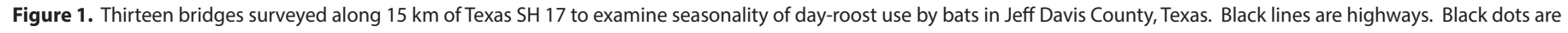
bridges. Numbers to the side of black dots correspond to bat species found roosting in each bridge. 
ciliolabrum as roosting in highway infrastructure, but $M$. californicus was reported using a bridge in central New Mexico (Geluso and Mink 2009).

Statistical analysis. We examined seasonality for the most common taxa (T. brasiliensis, M. velifer, M. californicus/ciliolabrum, and M. yumanensis) based on Generalized Linear Models (Hoffmann 2004). We used a negative binomial model with a log link function to evaluate effects of bridge, month, and month ${ }^{2}$ on number of individuals (or abundance class for $T$. brasiliensis). The bridge factor was included to account for non-independence of sampling the same bridges month after month. Month and month ${ }^{2}$ terms were used to evaluate if there was a quadratic (humpshaped) relationship between month and number of bats that would indicate seasonality. In some situations, correlations between bridges (measured across months) were so high that the Hessian matrix was singular. In these cases, we removed one or more bridges causing singularity.

\section{Results}

Day-roosting bats were observed at all 13 bridges examined in the Trans-Pecos region of western Texas. Descending rank order for number of observations of bat species were $T$. brasiliensis $(n>20,000), M$. velifer $(n=1,112), M$. californicus/ciliolabrum ( $n=147)$, M. yumanensis $(n=100)$, Antrozous pallidus $(n=37)$, and M. thysanodes $(n=3)$. All species with sufficient sample sizes for analysis (T. brasiliensis, M. velifer, M. californicus/ciliolaburm, and M. yumanensis) exhibited significant differences among bridges (Table 1)

Table 1. Results of Generalized Linear Models evaluating effects of bridge and month on numbers of bats per bridge along Texas SH 17. A significant bridge effect suggests bats are selecting particular bridges as day-roosts. A significant quadratic month term (i. e., month $^{2}$ ) indicates seasonality of bridge use by bats.

\begin{tabular}{|c|c|c|c|c|}
\hline Species & $\begin{array}{c}\text { Independent } \\
\text { Variable }\end{array}$ & $\begin{array}{l}\text { Wald } \\
\text { Chi }^{2}\end{array}$ & df & P-Value \\
\hline \multirow[t]{3}{*}{ Tadarida brasiliensis } & Bridge & 45.96 & 12 & $<0.001$ \\
\hline & Month & 0.25 & 1 & 0.616 \\
\hline & Month $^{2}$ & 0.19 & 1 & 0.667 \\
\hline \multirow[t]{3}{*}{ Myotis velifer } & Bridge & 50.41 & 11 & $<0.001$ \\
\hline & Month & 105.71 & 1 & $<0.001$ \\
\hline & Month $^{2}$ & 104.76 & 1 & $<0.001$ \\
\hline \multirow[t]{3}{*}{ M. c./ciliolabrum } & Bridge & 26.57 & 8 & 0.001 \\
\hline & Month & 22.58 & 1 & $<0.001$ \\
\hline & Month $^{2}$ & 23.58 & 1 & $<0.001$ \\
\hline \multirow[t]{3}{*}{ Myotis yumanensis } & Bridge & 23.48 & 10 & 0.009 \\
\hline & Month & 21.78 & 1 & $<0.001$ \\
\hline & Month $^{2}$ & 22.99 & 1 & $<0.001$ \\
\hline
\end{tabular}

suggesting that some bridges contained structural features or were located in areas more conducive for bats as dayroosts. Significant seasonality was exhibited by $M$. velifer, M. californicus/ciliolabrum and M. yumanensis but not for $T$. brasiliensis (Table 1) whereby bats used bridges at higher frequencies during warmer months (Figure 2).

Tadarida brasiliensis. Brazilian free-tailed bats roosted in bridges on Texas SH 17 in the greatest numbers. These bats colonized the northern four and one extreme southern bridges in large numbers, often $>5,000$ individuals per bridge. These northern and southern sites were separated by eight bridges and approximately $10 \mathrm{~km}$. It is likely that these represent at least two discrete colonies, one on the north side and one on the south side. Tadarida brasiliensis was encountered in small numbers $(<10)$ in five other bridges, whereas three bridges were not occupied at any time. In the five bridges that were lightly occupied, when we encountered $T$. brasiliensis, individuals were roosting singly or in small groups of two to three. Tadarida brasiliensis used bridges in high numbers in all months and did not demonstrate seasonality of bridge use (Table; Figure 2).

Myotis velifer. The cave myotis was the second most common bat encountered in bridges. This species was observed using every bridge at least twice during our 12-month observation period. Myotis velifer often roosted singly or doubly but was also occasionally found roosting in groups of 15 to 20 individuals. Myotis velifer roosted across the entire range of widths between expansion joints. This species often roosted alongside individuals of or even within large groups of T. brasiliensis. Because of its high abundance relative to other species of Myotis, M. velifer exhibited conspicuous seasonality (Table 1; Figure 2), being completely absent from bridges from December to February and represented by less than 15 individuals across all 13 bridges during the months of October, November and March.

Myotis californicus/ciliolabrum. This species complex was common and was encountered in eight bridges more than once, two bridges only once, and never in the three that were to the south near Fort Davis. Individuals almost always roosted singly in bridges. Often individuals roosted within one meter of another member of the complex, and when this occurred it was typically an individual of the opposite sex. Individuals almost exclusively roosted in the narrowest expansion grooves, just wide enough for the bats to fit. This species complex exhibited significant seasonality (Table 1; Figure 2). Due to its lower abundance, differences among months were less pronounced. During the months of December through February, individuals never used bridges as roosts. The greatest number of observations were in the months of May $(n=44)$, June $(n=25)$, and July $(n=37)$.

Myotis yumanensis. The Yuma myotis was encountered across all 13 bridges, but in low numbers. This species often roosted singly where the width between expansion joints was small and just large enough for them to fit. It was not encountered in bridges during the months of November through February. 
Tadarida brasiliensis
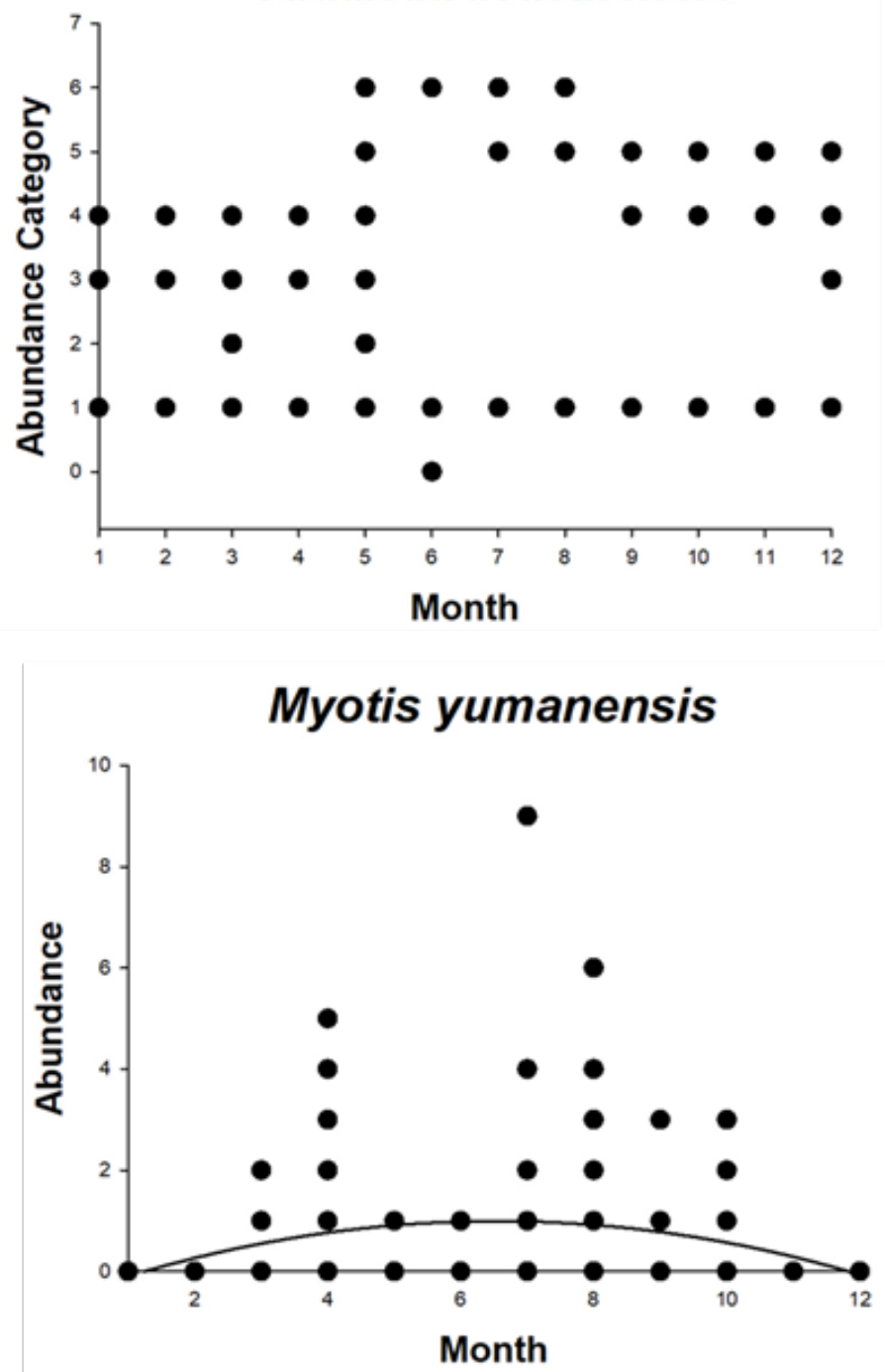

Myotis velifer

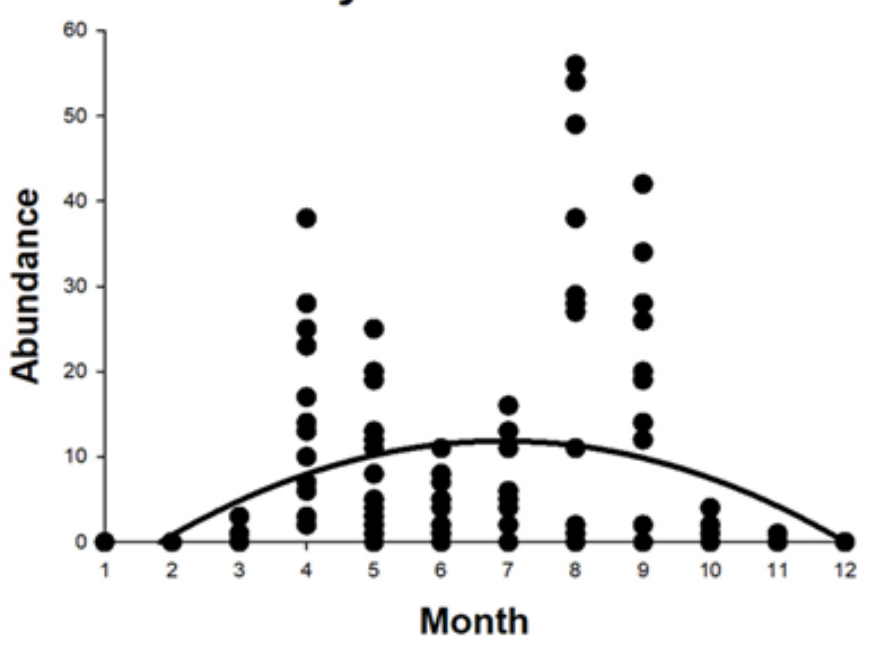

Myotis californicus/ciliolabrum

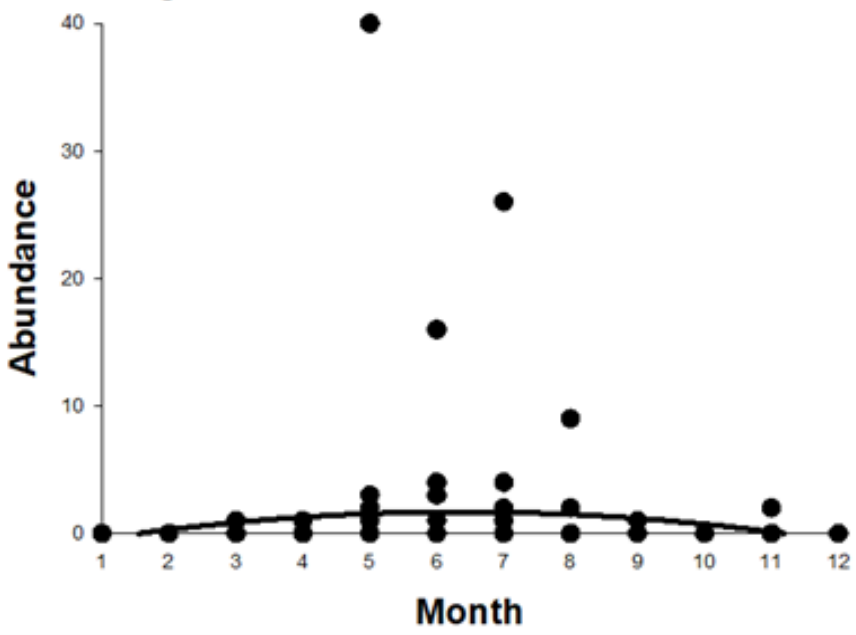

Figure 2. Abundance of bats per month measured across 13 bridges along 15 km of Texas SH 17 in Jeff Davis County.

Myotis thysanodes and Antrozous pallidus. These two species, while using bridges as day-roosts, were observed only rarely. Myotis thysanodes roosted singly the three times we observed it and was observed only in spring and fall during the months of May, September and October. Antrozous pallidus roosted singly and in groups. We encountered a maternity colony of 10 individuals of mixed ages (i. e., juveniles and adults) in late May and June, but this species also used bridges as day-roosts during the months of March, September and October. Antrozous pallidus always roosted in wide expansion joints that were closest to the exterior edge of the bridge.

\section{Discussion}

We documented bridges used as day-roosts by six bat species in the Trans-Pecos region of Texas. Substantive variation among bridges, as well as months, existed regarding numbers of bats roosting in bridges. Only T. brasiliensis used bridges as day-roosts across all seasons. No other taxa roosted in bridges from December to February, the coldest months in the Trans-Pecos. Significant differences among bridges regarding number of bats roosting in them suggest that bats were selecting particular bridge attributes such as length or height off the ground or perhaps something within the habitat where the bridge occurs.

Despite the high species richness of bats in the TransPecos, a limited number of species appear to inhabit bridges. However, those that do, do so with regularity. Corynorhinus townsendii, Eptesicus fuscus, Lasionycteris noctivagans, M. volans, Parastrellus hesperus, and Nyctinomops macrotis were all documented by Keely and Tuttle (1999) to occupy highway infrastructure and their geographic distributions overlap Jeff Davis County. However, we did not observe these species during our survey. Keely and Tuttle (1999) did not distinguish between bridge-use and culvertuse, so one possibility is that those species that went undetected by us roost in culverts and not bridges. Another possible explanation for absence of these taxa is differences in spatial extent between our and the Keeley and Tuttle (1999) studies. Keeley and Tuttle (1999) examined bridges and 
culverts across 25 different states, whereas we examined bridges within a single county. Most of the species listed in Keeley and Tuttle (1999) are relatively rare and are rarely encountered in our survey area (DeBaca 2008). Moreover, P. hesperus, N. macrotis, and C. townsendii are lowland species (DeBaca 2008) and may not occur in large numbers at the relatively high elevations $(1550 \mathrm{~m})$ around Fort Davis. Eptesicus fuscus, L. noctivagans, and $M$, volans are higher elevation species and would be expected to inhabit this region. In fact, E. fuscus and $M$. volans were two of the most commonly mist-netted bats in the Davis Mountains (DeBaca 2008), approximately $30 \mathrm{~km}$ from our survey area. Other possible explanations for why we did not encounter these species under bridges are that species are geographically variable in their tendencies to use highway infrastructure as day-roosts and they choose not to do so in this region, or these bridges did not possess characteristics that promote day-roosting by these species.

Of the bats we did encounter under bridges, rank abundances were consistent with other places in the Trans-Pecos where bats were mist-netted to determine species composition. For example, rank abundance of $T$. brasiliensis $>$ $M$. velifer $>M$. californicus/ciliolabrum $>M$. yumanensis $>M$. thysanodes is similar to that at Davis Mountains State Park (DeBaca 2008) and Big Bend Ranch State Park (Yancey 1997). Such agreement suggests that these bats are roosting in bridges at frequencies similar to their abundances in the region.

A notable observation was the year-round use of bridges as roosts by $T$. brasiliensis and their consistently high roosting frequency. Tadarida brasiliensis mexicana traditionally has been thought to migrate out of the TransPecos, and much of Texas, during winter (Schmidly 1977). A number of scattered records suggest that a small number of individuals remain in Texas to overwinter (Spenrath and LaVal 1974; Tuttle 2003; Keeley and Keeley 2004; Scales and Wilkins 2007; Weaver et al. 2015). A similar observation has been made in neighboring New Mexico (Geluso and Mink 2009). In 2018, Kasper and Yancey reported year-round roosting in large numbers in a single bridge in Big Bend Ranch State Park. Considering our results and these other studies, T. b. mexicana may overwinter in the Trans-Pecos at much higher frequency than originally thought. Moreover, global climate change is making winters milder (Sherwin et al. 2012), which may be contributing to T. b. mexicana overwintering in the Trans-Pecos. Migration has an associated risk (Fleming and Eby 2003; Popa-Lisseanu and Voigt 2009), and in a warming climate risk may outweigh the benefits of migration. Climate change may be contributing to an increase in T. b. mexicana populations in Texas during winter (Kasper and Yancey 2018; Weaver et al. 2015).

Seasonality of use of highway infrastructure by bats also has methodological implications. Bats may not use highway infrastructure as roosts during all seasons and surveys should be conducted during seasons when bats actively use these structures. Bats exhibit species-specific seasonality of use of bridges as roosting sites as witnessed here by comparing $T$. brasiliensis to the other species examined. Other species of bats, especially those found in the southeastern portion of the United States including P. subflavus, M. austroriparius, and C. rafinesquii, may use highway infrastructure with greater frequency in winter (Rice 1957; Stevens et al. 2017; Lutsch 2019; Meierhofer et al. 2019) than summer. A dynamic interplay exists regarding use of anthropogenic structures as roosting sites by bats and this is likely dictated by species-specific, season-specific, and habitat-specific influences that are deserving of future study.

\section{Acknowledgments}

We dedicate this publication to Dr. David J. Schmidly. Dr. Schmidly has been the leader of Texas Mammalogy for decades. His many contributions, either from his own research or through facilitation of that of others through administration, collaboration, or coordination with state and federal agencies will be highly regarded for decades to come. We thank Heidi Amarilla-Stevens for translating the abstract to Spanish.

\section{Literature Cited}

Ammerman, L. K., C. L. Hice, AND D. J. Schmidly. 2012. Bats of Texas, Texas A\&M University Press. College Station, U.S.A.

Bender, M. J., S. B. Castleberry, D. A. Miller, and T. B. WigLEY. 2010. Use of culverts as diurnal roost by bats in Butler Co. Alabama. Journal of the Alabama Academy of Science 81:204-209.

Brigham, R. M. and M. B. Fenton. 1986. The influence of roost closure on the roosting and foraging behavior of Eptesicus fuscus (Chiroptera: Vespertilionidae). Canadian Journal of Zoology 64:1128-1133.

Constantine, D. G. 1958. Ecological observations on lasiurine bats in Georgia. Journal of Mammalogy 39:64-70.

Constantine, D. G. 1998. An overlooked external character to differentiate Myotis californicus and Myotis ciliolabrum (Vespertilionidae). Journal of Mammalogy 79:624-630.

Davis, R. AND E. L. Cockrum. 1963. Bridges utilized as day roosts by bats. Journal of Mammalogy 44:428-430.

Davis, R. B., C. F. Herreid, II, AND H. L. Short. 1962. Mexican free-tailed bats in Texas. Ecological Monographs 32:311-346. DeBACA, R. S. 2008. Distribution of mammals in the Davis Mountains, Texas and surrounding areas. Ph.D. Dissertation, Texas Tech University. Lubbock, U.S.A.

Feldhamer, G. A., T. C. Carter, A. T. Morzillo and E. H. Nicholson. 2003. Use of bridges as day roosts by bats in southern Illinois. Transactions of the Illinois State Academy of Science 96:107-112.

Felts, J. W. and W. D. Webster. 2003. Use of bridges as daytime roosts by bats in southeastern North Carolina. Journal of the North Carolina Academy of Science 119:172-178.

Fenton, M. B. 1970. Population studies of Myotis lucifugus (Chiroptera: Vespertilionidae) in Ontario. Life Sciences Contributions of the Royal Ontario Museum 77:1-34.

Fleming, T. H., AND P. Eby. 2003. Ecology of bat migration. Pages 156-193 in Bat Ecology (Kunz, T. H., and M. B. Fenton, eds.), University of Chicago Press. Chicago, U.S.A. 
Higginbotham, J. L., and L. K. Ammerman. 2002. Chiropteran community structure and seasonal dynamics in Big Bend National Park. Special Publications, Museum of Texas Tech University 44:1:44.

Humphrey, S. R., AND J. B. Cope. 1976. Population ecology of the little brown bat, Myotis lucifugus, in Indiana and north-central Kentucky. Special Publications of the American Society of Mammalogists 4:1-81.

Geluso, K. AND J. N. Mink. 2009. Use of bridges by bats (Mammalia: Chiroptera) in the Rio Grande Valley, New Mexico. Southwestern Naturalist 54:421-429.

Hoffmann, J. P. 2004. Generalized Linear Models: an applied approach. Pearson Press. Boston, U.S.A.

Holloway, G. L., AND R. M. R. Barclay. 2001. Myotis ciliolabrum. Mammalian Species 670:1-5,

Kalcounis-Ruppell, M. C., J. M. Psyllakis, and R. M. Brigham. 2005. Tree roost selection by bats: an empirical synthesis using meta-analysis. Wildlife Society Bulletin 33:1123-1132.

Kasper, S., AND F. D. YanceY, II. 2018. Year-round bridge colony of Mexican free-tailed bats (Tadarida brasiliensis mexicana) in Trans-Pecos Texas. Texas Journal of Science 70:Article 4.

Keeley, A. T. H., And B. W. Keeley. 2004. The mating system of Tadarida brasiliensis (Chiroptera: Molossidae) in a large highway bridge colony. Journal of Mammalogy 85:113-119.

Keeley, B. W., And M. D. Tuttle. 1999. Bats in American bridges. Bat Conservation International, Inc, Resource Publication. Austin, U.S.A.

Krejsa, D. M., S. K. Decker, And L. K. Ammerman. 2020. Noteworthy records of 14 bat species in Texas including the first record of Leptonycteris yerbabuenae and the second record of Myotis occultus. Occasional Papers, Museum of Texas Tech University 368:1-10.

Kunz, T. H. 1982. Roosting ecology. Pages 1-46, in Ecology of Bats (Kunz, T. H., ed.). Plenum Press. New York, U.S.A.

Kunz, T. H., ANd L. F. Lumsden. 2003. Ecology of cavity and foliage roosting bats. Pages 3-89 in Bat Ecology (Kunz, T. H., and M. B. Fenton, eds.), University of Chicago Press. Chicago, U.S.A.

Kunz, T. H., And E. D. Pierson. 1994. Bats of the world: an introduction. Pp. 1-46, in Walker's Bats of the World (Nowak, R. M., ed.). Johns Hopkins University Press. Baltimore, U.S.A.

Lutsch, K. 2019. Assessment of culverts and bridges as roosting habitat for Perimyotis subflavus and disease transmission corridors for Pseudogymnoascus destructans. M. S. Thesis, Kennesaw State University. Kennesaw, U.S.A.

Meierhofer, M. B., S. J. Leivers, R. R. Fern, L. K. Wolf, J. H. Young, JR., B. L. Pierce, J. W. Evans, and M. L. Morrison. 2019. Structural and environmental predictors of presence and abundance of tri-colored bats in Texas culverts. Journal of Mammalogy 100:1274-1281.

Meierhofer, M. B., H.-H. Wang, W. E. Grant, J. H. Yong JR., L. H. Johnston, L. K. Wolf, J. E. Evans, B. L. Pierce, J. M. SzewczaK, AND M. L. Morrison. 2018. Use of box-beam bridges as day roosts by Mexican free-tailed bats (Tadarida brasiliensis) in Texas. Southeastern Naturalist 17:605-615.

Mering, E. D., And C. L. Chambers. 2014. Thinking outside the box: a review of artificial roosts for bats. Wildlife Society Bulletin 38:741-751.

Pierson, E. D. 1998. Tall trees, deep holes and scarred landscapes: conservation biology of North American bats. Pages
309-325, in Bat Biology and Conservation (Kunz, T. H., and P. A. Racey, eds.), Smithsonian Institution Press. Washington, U.S.A. Popa-Lisseanu, A. G., And C. C. Voigt. 2009. Bats on the move. Journal of Mammalogy 90:1283-1289.

RıCE, D. W. 1957. Ecology of Myotis austroriparius in Florida. Journal of Mammalogy 38:15-32.

SCAles, J. A., AND K. T. Wilkins. 2007. Seasonality and fidelity in roost use of the Mexican free-tailed bat, Tadarida brasiliensis, in an urban setting. Western North American Naturalist 67:402-408.

Schmidly, D. J. 1977. Mammals of the Trans-Pecos including Big Bend National Park and Guadalupe Mountains National Park. Texas A\&M University Press. College Station, U.S.A.

Schmidly, D. J., AND R. D. Bradery. 2016. The mammals of Texas. University of Texas Press. Austin, U.S.A.

Sherwin, H. A., W. I. Montgomery, And M. G. Lundy. 2012. The impact and implications of climate change for bats. Mammal Review 43:171-182.

Spenrath, C. A. and R. K. LaVal. 1974. An ecological study of a resident population of Tadarida brasiliensis in eastern Texas. Occasional Papers, Museum of Texas Tech University 21: 1-14.

Stevens, R. D., C. J. Garcia, E. E. Bohlender, and B. B. Gregory. 2017. Distributional updates and conservation status of bats from Louisiana. Occasional Papers, Museum of Texas Tech University 348:1-12.

Tutrle, M. D. 2003. Texas bats. Bat Conservation International, Austin, Texas.

Vaughan, T. A., And T. J. O'Shea. 1976. Roosting ecology of the pallid bat, Antrozous pallidus. Journal of Mammalogy 57:19-42.

Weaver, S. P., T. R. Simpson, J. T. Baccus, AND F. W. Weckerly. 2015. Baseline population estimates and microclimate data for newly established overwintering Brazilian free-tailed bat colonies in central Texas. Southwestern Naturalist 60:151-157.

YanceY, F. D., II. 1997. The mammals of Big Bend Ranch State Park, Texas. Special Publications, Museum of Texas Tech University 39:1-210.

Associated editor: Lisa and Robert Bradley

Submitted: October 2, 2020; Reviewed: March 5, 2021;

Accepted:March 31, 2021; Published on line:May 28, 2021. 